\title{
Preferences of the Central Reserve Bank of Peru and Optimal Monetary Rules in the Inflation Targeting Regime
}

\author{
Nilda Mercedes Cabrera Pasca \\ Doutoranda em Economia, Pontifícia Universidade Católica do Rio de Janeiro (PUC-RJ) \\ Endereço para contato: Rua Marquês de São Vicente, 225, sala 210-F - Gávea. \\ Rio de Janeiro - RJ - CEP: 22451-900. \\ Email: nilda.pasca@econ.puc-rio.br
}

\section{Edilean Kleber da Silva Bejarno Aragón}

Professor do PPGE - Universidade Federal da Paraíba (UFPB)

Programa de Pós-Graduação em Economia - Endereço para contato: Jardim Cid. Universitária João Pessoa - PB - CEP: 58.051-900.

Email: edilean@hotmail.com

\section{Marcelo Savino Portugal}

Professor do PPGE e PPGA - Universidade Federal do Rio Grande do Sul (UFRGS) e Pesquisador CNPq - Faculdade de Ciências Econômicas - Programa de Pós-Graduação em Economia Av. João Pessoa, 52 sala 33 B - $3^{\circ}$ andar - Centro - Porto Alegre-RS - CEP: 90040-000.

Email: msp@ufrgs.br

Recebido em 22 de maio de 2011 . Aceito em 11 de outubro de 2011.

\begin{abstract}
This study aims to identify the preferences of the monetary authority in the Peruvian regime of inflation targeting through the derivation of optimal monetary rules. To achieve that, we used a calibration strategy based on the choice of values of the parameters of preferences that minimize the square deviation between the true interest rate and interest rate optimal simulation. The results showed that the monetary authority has applied a system of flexible inflation targeting, prioritizing the stabilization of inflation, but without disregarding gradualism in interest rates. On the other hand, concern over output stabilization has been minimal, revealing that the output gap has been important because it contains information about future inflation and not because it is considered a variable goal in itself. Finally, when the smoothing of the nominal exchange rate is considered in the loss function of the monetary authority, the rank order of preferences has been maintained and the smoothing of the exchange rate proved insignificant.
\end{abstract}

\section{Keywords}

inflation target, central bank preferences, optimal monetary rules, Central Bank of Peru 


\title{
JEL Classification
}

\author{
C61, E52, E58
}

\section{Resumo}

Este estudo objetiva identificar as preferências da autoridade monetária peruana sob o regime de metas de inflação através da derivação de regras monetárias ótimas. Para atingir tal objetivo, nós usamos uma estratégia de calibração baseada na escolha dos valores dos parâmetros de preferências que minimizam o desvio quadrático entre a verdadeira taxa de juros e a taxa de juros ótima simulada. Os resultados evidenciaram que autoridade monetária tem aplicado um regime de metas de inflação flexível, priorizando a estabilização da inflação, mas sem ter desprezado o gradualismo da taxa de juros. Por outro lado, a preocupação pela estabilização do produto tem sido mínima, revelando que o hiato do produto tem sido importante porque ela contém informação sobre a inflação futura e não porque seja considerada como uma variável meta em si mesma. Finalmente, quando o suavizamento da taxa de câmbio nominal é considerado na função perda da autoridade monetária, a ordem de importância das preferências tem-se mantido, e o suavizamento da taxa de câmbio apresentou um peso insignificante.

\section{Palavras-Chave}

metas de inflação, preferências do banco central, regras monetárias ótimas, Banco Central do Peru

\section{Introduction}

In recent years, a large number of academic researchers, as well as of researchers from other areas, have strived to unravel the real incentives associated with policymakers' actions in response to macroeconomic development. Their justification is that monetary policy follows a systematic strategy, driven by preferences related to the achievement of certain targets.

The empirical literature in the past two decades has produced evidence in favor of improved efficiency of monetary policy in countries which have adopted the inflation targeting regime. In the case of Peru, this regime was formally introduced in 2002 and, even though inflation targets had been announced since 1994, there was no explicit institutional commitment towards their accomplishment. Under the new regime, however, the Peruvian monetary authority lifted the control over the monetary base as policy instrument and propounded an interest rate announcement policy. In this case, the Central Reserve Bank of Peru (CRBP) establishes its monetary policy instrument in order to meet the targets outlined for the economic variables, such as inflation or output, in which the weights attached 
to the loss function depend on the preferences given to each of the established goals. On the other hand, notwithstanding an evident policy geared towards price stability in an inflation targeting regime, the monetary authority is less clear about its other monetary policy goals.

Given the objectives and the instrument by which the monetary authority is guided in the inflation targeting regime, it is possible to rely on a functional relation (monetary rule) that combines both elements and that also considers relevant economic variables. Therefore, ever since the seminal work by Taylor (1993), several monetary policy rule specifications have been proposed to describe the response of central banks to economic variables. Conversely, in theory, the interest rate rules can be derived as the solution to an intertemporal optimization problem restricted to the economic structure, where the monetary authority seeks to minimize the loss associated with deviations of the objective variables from their respective targets. ${ }^{1}$ Nevertheless, as shown by Svensson (1999), the coefficients of the interest rate rules derived through this method are complex combinations of the parameters correlated with the economic structure and with the monetary authority's preferences.

The present paper aims to identify the preferences of the Peruvian monetary authority under the inflation targeting regime by deriving optimal monetary rules. Knowing about the preferences of the authority in charge of the monetary policy is paramount, not only because this will allow understanding the conduct of the interest rate policy, i.e., it will be possible to verify whether the observed economic results are compatible with an optimal monetary policy, but also because of its influence on the formation of future expectations by economic agents. Due to the important role of expectations in determining macroeconomic variables, the identification of monetary authority's preferences becomes even more important. Finally, this will also allow us to know what economic variables enter the loss function.

In the present study, we will infer the preferences of the CRBP by applying a calibration strategy. Basically, this strategy is based on the selection of preference parameter values that minimize the squared

${ }^{1}$ For further details, see Walsh (2003), Svensson (1999), Castelnuevo and Surico (2003). 
deviation between the actual interest rate path and a simulated optimal interest rate.

It is necessary to underscore, though, that the proposed method is different from those applied to Peru. For instance, GMM, applied by Rodriguez (2008), is based on the estimation of a three-equation system, namely: supply curves, demand curves and an equation for the monetary rule that solves the central bank's optimization problem, and whose results rely on the imposition of a finite policy horizon (four quarters) for the problem with the monetary authority. In our work, it is not necessary to impose a finite horizon, and just like Rodriguez (2008), we will use information on economic constraint to solve the stochastic linear regulator problem. On the other hand, Bejarano (2001) estimates a VAR to capture the dynamics of the economy, but he refers to a simple model for estimation of the preferences of the Peruvian central bank.

Most of the international literature on policymakers' preferences has been devoted to estimating Federal Reserve (FED) preferences. Some noteworthy studies include the following: Salemi (1995), on the use of the optimal linear quadratic control described by Chow (1981); Dennis (2006), Dennis (2004) and Ozlale (2003), on maximum likelihood; Favero and Rovelli (2003), on GMM; 1lbas (2008), on Bayesian methods; Söderlind et al. (2002) and Castelnuevo and Surico (2003), on a calibration process. These studies demonstrated that the FED has given greater preference for inflation stabilization as well as for interest rate smoothing, whereas output stabilization appears to have been neglected.

The international literature also addresses preference estimations for other central banks in addition to the FED. For instance, Cecchetti and Ehrmann (1999) estimated preferences for 23 countries (including nine inflation targeters) and Cecchetti et al. (2002) estimated preferences for central banks of countries belonging to the European Monetary Union. In both studies, the authors used VAR and found evidence that the trade-off between inflation and output has varied considerably among different countries, with heavier weight being placed on inflation rather than on output variability. Collins and Siklos (2004) estimated the preferences for central banks of Canada, Australia, New Zealand and the United States (USA), using GMM, and found that central banks can be described by an optimal 
inflation targeting regime with significant weight on interest rate smoothing and a lesser weight on the output gap. Tachibana (2003) estimated the preferences for central banks of Japan, the UK and the USA after the first oil shock. The author showed that these countries increased their aversion to inflation volatility, especially from the 1980s onwards. Rodriguez (2008) estimated the preferences for the Bank of Canada for different subsamples and, to that purpose, he used GMM. The author evidenced that the monetary authority's preferences changed across regimes, chiefly the parameter associated with the implicit inflation target, which has significantly decreased. Finally, Aragón and Portugal (2009) identified the preferences of the Central Bank of Brazil (CBB) in the inflation targeting regime using a calibration process and found evidence that the CBB adopted a flexible inflation targeting regime, placing larger emphasis on inflation stabilization. Moreover, the authors showed that the CBB was much more concerned with the smoothing of the Selic interest rate than with output stabilization.

Empirical studies on the preferences of the CRBP are scarce. Within this line of research, we highlight three studies: Goñi and Ormeño (2000), using GMM and monetary base as monetary policy instrument, determined the preferences of CRBP for the 1990s. The authors found that the CRBP had a greater preference for inflation stabilization and for exchange rate depreciation and a lesser preference for the output gap. In the same vein as Cecchetti and Krause (2001) and Cecchetti and Ehrmann (1999), Bejarano (2001) estimated the preferences of the CRBP for the 1990s. The author demonstrated that the CRBP had a larger preference for inflation rather than for output variability, concluding that the behavior of monetary policy in the 1990s was not far from inflation targeting. Finally, Rodriguez (2008), following Favero and Rovelli (2003), estimates the preferences of the CRBP for different regimes. ${ }^{2}$ Using GMM, the author found evidence that the implicit inflation target has significantly decreased and that the Peruvian monetary policy may have been efficiently conducted in the last regime (1994:2-2005:4).

The present paper contributes to the existing empirical literature on Peru using a different sample, specifically the inflation targeting regime, and also a different method (calibration) to determi-

2 For further details on the classification of monetary policy regimes in Peru, see Castillo et al. (2007a). 
ne the preferences of the CRBP. Results showed that the Peruvian monetary authority in the inflation targeting regime has adopted a flexible monetary policy, being largely concerned with inflation stability, followed by considerable concern with interest rate smoothing. However, the preference for output stability and exchange rate smoothing has been negligible.

Our study is organized into three sections, in addition to the introduction. Section 2 shows the development of the theoretical model and the central bank's optimization problem, as well as the strategy for calibration of the monetary authority's preferences. Section 3 addresses the estimation results for the structure of the economy and identifies the preferences of the Peruvian monetary authority, based on a monetary policy analysis. Section 4 concludes.

\section{The Macroeconomic Model}

The CRBP has a dynamic optimal control problem whose solution is contemplated in its policy actions. These are the optimal responses of the monetary authority to economic development, which are captured by the relationships between state variables and the control variable (the monetary policy instrument).

In what follows, we describe the dynamics of the state variables based on the structure of the economy that restricts the policymaker's optimization problem as well as the derivation of the optimal monetary rule. Finally, we show the steps used in the calibration strategy for determining the policy preferences of the CRBP.

\subsection{Economic Structure}

When central banks optimize, they are subject to the restriction imposed by the behavior of the economic structure. In this paper, we describe a structural macroeconomic model for the Peruvian economy with backward-looking expectations. The proposed model is based on Rudebusch and Svensson $(1998,1999)$ and Aragón and Portugal (2009). The dynamics governing the four equations that make up the model is given by: 


$$
\begin{gathered}
\pi_{t+1}=\alpha_{1} \pi_{t}+\alpha_{2} \pi_{t-1}+\left(1-\alpha_{1}-\alpha_{2}-\alpha_{4}\right) \pi_{t-2}+\alpha_{4}\left(q_{t}-q_{t-1}\right)+\alpha_{5} y_{t-1}+\xi_{\pi, t+1} \\
y_{t+1}=\beta_{1} y_{t}+\beta_{2} y_{t-1}+\beta_{3} r_{t-1}+\beta_{4} t t_{t}+\xi_{y, t+1} \\
q_{t+1}=q_{t}+\xi_{q, t+1} \\
t t_{t+1}=\gamma_{1} t t_{t}+\xi_{t t, t+1}
\end{gathered}
$$

where: $\pi_{t}$ is the annualized quarterly inflation rate, measured by $400 *\left(\log \left(p_{t}\right)-\log \left(p_{t-1}\right)\right)$, where $p_{t}$ is the consumer price index for the metropolitan region of Lima; $q_{t}$ is the nominal exchange rate; $y_{t}$ is the output gap percentage between the real GDP and potential GDP, i.e., $y_{t}=100 *\left(\log \left(G D P_{t}\right)-\log \left(G D P_{t}^{*}\right)\right)$, where $G D P_{t}$ and $G D P^{*}$ are the real and potential gross domestic product, respectively; $t t_{t}$ is the terms of trade gap defined as the percentage difference of the terms of trade from their trend, i.e., $t t_{t}=100 *\left(\log \left(t t_{\text {real }, t}\right)-\log \left(t t_{t}^{*}\right)\right)$, where $t t_{\text {real }}$ denotes the terms of trade index and $t t_{t}^{*}$ is the potential terms of trade index. For the gap variables, the trend values were calculated using the HodrickPrescott filter. Finally, $r_{t}$ stands for the real interest rate, defined as the difference between the nominal interest rate and regarded as monetary policy instrument, $i_{t}$, and inflation rate, $\pi_{t}$. All variables are expressed as deviations from the mean; therefore, no constant appears in system (1) - (4). The terms $\xi_{\pi, t+1}, \xi_{y, t+1}, \xi_{q, t+1}$ and $\xi_{t t, t+1}$ are construed as supply shocks, demand shocks, exchange rate shocks and terms of trade shocks, respectively.

Equation (1) can be seen as a Phillips curve that shows that the current inflation rate depends on its lagged values, on the fluctuation of the exchange rate in the previous period and on the two-period lag of the output gap. The verticality of the Phillips curve is imposed by the restriction that the sum of the lagged inflation parameters and of the fluctuation in the exchange rate should be equal to 1 . This means that any exchange rate depreciation is totally transferred to prices in the long run.

The IS curve, expressed by Equation (2), shows the relationship of the output gap with its lagged values, with the real interest rate 
lagged two periods and with the terms of trade gap lagged one period. ${ }^{3}$ The importance to include the latter variable in the aggregate demand equation is that, because Peru has a small open economy, it is vulnerable to external shocks that affect the aggregate demand. The terms of trade, which have a close relationship with economic fluctuations, mainly after the implementation of the inflation targeting regime (Castillo et al., 2007b), ${ }^{4}$ are one of the variables that capture this vulnerability.

According to Equations (3) and (4), the exchange rate is assumed to follow a random walk and the terms of trade are believed to follow a first-order autoregressive process for the sake of simplification of the model. ${ }^{5}$

The coefficients that follow the exchange rate depreciation and the output gap in the Phillips curve equation are expected to be positive, i.e. $\alpha_{3}>0$ and $\alpha_{4}>0$, respectively. In addition, a negative sign is expected for the real interest rate coefficient in the IS curve equation, $\beta_{3}<0$, and so is a positive sign for the terms of trade coefficient, $\gamma_{1}>0$.

Although the model described here is parsimonious, it has two advantages: i) it simplifies the solution to the intertemporal optimization problem by the policymaker, as it simplifies that statespace representation of the economic structure; and ii) it captures an important channel for the transmission of monetary policy, the aggregate demand channel. In regard to the latter, an increase in the interest rate, $i_{t}$, which causes the real interest rate to deviate from its long-term trend, reduces the output gap after two quarters and the inflation rate after four quarters.

While the empirical success of the proposed model has been documented by studies conducted for developed economies, such as the works of Rudebusch and Svensson $(1998,1999)$ for the USA, and for emerging economies, undertaken by Aragón and Portugal (2009) for

3 The assumption that the output gap depends on the real interest rate lagged two periods is supported by the analysis of cross-correlograms and by the evidence provided by Castillo et al. (2007b, p.35).

4 The importance of terms of trade to the Peruvian aggregate demand is highlighted by Castillo et al. (2007b) and by the Modelo de Proyección Trimestral del BCRP (2009).

5 The assumption that the exchange rate equation follows a random walk is based on the best fit for these data, as described in Section 3. 
Brazil, it is important to pinpoint the advantages and disadvantages of using this type of backward-looking models.

Backward-looking models have been supported by both academic economists and monetary authorities, and their application in several research studies is frequent, as occurs in Rudebusch and Svensson (1998, 1999), Favero and Rovelli (2003), Ozlale (2003), Dennis (2006), Collins and Skilos (2004), among others. In addition, Fuhrer (1997) compared backward-looking and forward-looking models, with favorable results for the former. According to Estrella and Fuhrer (2002), models with forward-looking expectations tend not to fit the data well, unlike the models proposed by Rudebusch and Svensson $(1998,1999)$. Woodford $(2000,2004)$, however, ascribes the fact that monetary policy is optimal, to some extent, to its history, or in other words, to its backward-looking behavior. Finally, models that employ rational expectations have been often unable to do without backward-looking elements in models for the structure of the economy (Collins and Skilos, 2004).

On the other hand, backward-looking models show considerable parameter instability, and are subject to the Lucas critique (Lucas, 1976). To overcome this hindrance, in the present paper, we consider one single monetary regime such as the "inflation targeting regime."

\subsection{Central Bank Preferences and Optimal Monetary Policy}

The monetary authority's goal is to minimize the value expected from the loss function:

$$
E_{t} \sum_{\tau=0}^{\infty} \delta^{\tau} \operatorname{LOSS}_{t+\tau}
$$

where:

$$
\operatorname{LOSS}_{t}=\lambda_{\pi}\left(\pi_{t}^{a}-\pi^{*}\right)^{2}+\lambda_{y} y_{t}^{2}+\lambda_{\Delta_{i}}\left(i_{t}-i_{t-1}\right)^{2}
$$

where $\delta$ is the intertemporal discount rate, $0<\delta<1, E_{t}$ is the expectations operator conditional on the set of information available at $t$ and in which all weights are greater than or equal 
to zero, $\lambda_{\pi} \geq 0, \lambda_{y} \geq 0$ and $\lambda_{\Delta_{i}} \geq 0 .{ }^{6}$ With this objective function, the monetary authority is assumed to stabilize annual inflation, $\pi_{t}^{a}=\frac{1}{4} \sum_{j=0}^{3} \pi_{t-j}$, around an inflation target, $\pi^{*}$, to maintain the output gap closed at zero and to smooth the nominal interest rate.

We take for granted that the inflation target is fixed over time and normalized to zero given that all variables are expressed as deviations from their respective means. ${ }^{7}$ Output gap targets and interest rate smoothing are also assumed to be zero. The parameters that measure the monetary authority's policy preferences, $\lambda_{\pi}, \lambda_{y}$ and $\lambda_{\Delta_{i}}$, indicate the importance given by the monetary authority to stabilization of inflation and of the output gap, and to interest rate smoothing, respectively. Finally, we assume that policy preferences add up to one, i.e., $\lambda_{\pi}+\lambda_{y}+\lambda_{\Delta_{i}}=1$.

The formulation of the loss function in (6) has been commonly used in the literature to identify central bank preferences, and is attractive for numerous reasons. First, a quadratic loss function subject to a linear restriction facilitates the derivation of optimal monetary rules by means of restricted optimization methods, specifically with respect to the stochastic linear regulator problem. ${ }^{8}$ Second, the specification of loss function (6) allows the monetary authority to smooth the nominal interest rate, in addition to the goals of stabilization of inflation and output. Finally, as shown by Woodford (2002), a specification of loss function similar to (6) can be derived as a second-order approximation of an intertemporal utility function of the representative agent.

Many are the reasons for including interest rate smoothing in the central bank's loss function. Amongst the most common reasons, we highlight the following: uncertainty over the key economic parameters caused by uncertainty over economic information that, consequently, encourages the central bank to adopt prudent monetary policy actions in an attempt to reduce uncertainty costs (Castelnuovo

6 When discount factor $\delta \rightarrow 0$, intertemporal loss function (6) approaches the unconditional mean of the loss function at time t: $E\left[\operatorname{LOSS}_{t}\right]=\lambda_{\pi} \operatorname{Var}\left[\pi_{t}^{a}-\pi^{*}\right]+\lambda_{y} \operatorname{Var}\left[y_{t}\right]+\lambda_{\Delta} \operatorname{Var}\left[i_{t}-i_{t-1}\right]$ (see Rudebusch and Svensson, 1999).

7 Expressing all the variables that restrict the structure of the economy to deviation of the mean from the inflation target normalized at zero does not alter the derivation of monetary authority's preferences, as demonstrated by Dennis (2006), Castelnuevo and Surico (2003) and Ozlale (2003).

8 For further details, see Miranda and Fackler (2002, p. 233) and Ljungqvist and Sargent (2004, p.110-114) 
and Surico, 2003, Sack and Wieland, 1999); difficulty in understanding whether the problems under analysis originate from merely economic shocks or from measurement errors in the data; large interest rate oscillations may lead to loss of reputation or of credibility of the monetary authority (Dennis, 2006); large interest rate volatility may result in capital loss, thus impairing the financial sector (Ozlale, 2003); announcement of a short disinflation horizon might not measure up to the expectations of the economic agents and, therefore, it might not be dependable, requiring some gradualism (Rojas, 2002). Finally, the inclusion of interest rate smoothing together with other relevant variables (such as inflation, output and exchange rate) for a small open economy is crucial in an inflation target regime in order to try to meet the inflation target.

In the current inflation targeting regime, the Peruvian monetary authority has apparently paid a lot of attention to the evolutionary behavior of the exchange rate. In the present study, this possibility is contemplated for the following reasons. First, unlike other emerging economies which have adopted the inflation targeting regime, the Peruvian currency is partially dollar-pegged, where the exchange rate is the most relevant financial asset price for the stability of the financial system. Thus, in dollarized economies such as Peru, abrupt exchange rate fluctuations result in high costs for the financial system, as well as for families whose debts are denominated in U.S. dollars (Reporte inflação BCRP, 2009). Second, monetary authority's interventions in the exchange rate market are believed to have a disguised precautionary motive - accumulation of international reserves to tackle negative external shocks. ${ }^{9}$ Given these aspects, a second exercise was developed, where exchange rate smoothing, $\Delta_{q}$, is regarded as the fourth goal of the Peruvian monetary authority. In this case, the loss function is described as:

$\operatorname{LOSS}_{t}=\lambda_{\pi}\left(\pi_{t}^{a}-\pi^{*}\right)^{2}+\lambda_{y} y_{t}^{2}+\lambda_{\Delta_{i}}\left(i_{t}-i_{t-1}\right)^{2}+\lambda_{\Delta q}\left(q_{t}-q_{t-1}\right)^{2}$

where the sum of the coefficients is assumed to be one, i.e., $\lambda_{\pi}+\lambda_{y}+\lambda_{\Delta_{i}}+\lambda_{\Delta_{q}}=1$.

To derive the optimal monetary rule, first we have to set the optimization restriction in state-space form. The restriction on the

9 For further details on CRBP interventions in the exchange rate market, see Reporte Inflação $(2008,2009)$. 
optimization problem is described by the structure of the economy, given by system (1)-(4). This system has a convenient state-space representation, given by:

$$
X_{t+1}=A X_{t}+B i_{t}+\xi_{t+1}
$$

Where the elements of Equation (8) are given by:

$$
X_{t}^{\prime}=\left[\begin{array}{llllllllll}
\pi_{t} & \pi_{t-1} & \pi_{t-2} & \pi_{t-3} & y_{t} & y_{t-1} & q_{t} & q_{t-1} & t t_{t} & i_{t-1}
\end{array}\right]^{\prime}
$$

$$
A=\left[\begin{array}{ccccccccccc}
\alpha_{1} & \alpha_{2} & 1-\alpha_{1}-\alpha_{2}-\alpha_{4} & 0 & 0 & \alpha_{5} & \alpha_{4} & -\alpha_{4} & 0 & 0 \\
1 & 0 & 0 & 0 & 0 & 0 & 0 & 0 & 0 & 0 \\
0 & 1 & 0 & 0 & 0 & 0 & 0 & 0 & 0 & 0 \\
0 & 0 & 1 & 0 & 0 & 0 & 0 & 0 & 0 & 0 \\
-\beta_{3} & 0 & 0 & 0 & \beta_{1} & \beta_{2} & 0 & 0 & \beta_{4} & \beta_{3} \\
0 & 0 & 0 & 0 & 1 & 0 & 0 & 0 & 0 & 0 \\
0 & 0 & 0 & 0 & 0 & 0 & 1 & 0 & 0 & 0 \\
0 & 0 & 0 & 0 & 0 & 0 & 1 & 0 & 0 & 0 \\
0 & 0 & 0 & 0 & 0 & 0 & 0 & 0 & \gamma_{1} & 0 \\
0 & 0 & 0 & 0 & 0 & 0 & 0 & 0 & 0 & 0
\end{array}\right] ; B=\left[\begin{array}{l}
0 \\
0 \\
0 \\
0 \\
0 \\
0 \\
0 \\
0 \\
0 \\
1
\end{array}\right] ; \xi_{t+1}=\left[\begin{array}{c}
\xi_{\pi, t+1} \\
0 \\
0 \\
0 \\
\xi_{y, t+1} \\
0 \\
\xi_{q, t+1} \\
0 \\
\xi_{t, t+1} \\
0
\end{array}\right]
$$

where $X_{t+1}$ is a $10 \mathrm{xl}$ vector, which represents the state variables, $i_{t}$ is the control variable for the policy (nominal interest rate) and $\xi_{t+1}$ is a vector containing supply and demand shocks, which are assumed to be normally i.i.d with zero mean and constant variances.

After that, the central bank's loss function must be set in its matrix form. To do that, it is necessary to express it in terms of state and control variables, as follows:

$$
Z_{t}=C_{x} X_{t}+C_{i} i_{t}
$$


where: ${ }^{10}$

$$
Z_{t}=\left[\begin{array}{c}
\pi_{t}^{a} \\
y_{t} \\
i_{t}+i_{t-1}
\end{array}\right] ; C_{x}=\left[\begin{array}{ccccccccc}
1 / 4 & 1 / 4 & 1 / 4 & 1 / 4 & 0 & 0 & 0 & 0 & 0 \\
0 & 0 & 0 & 0 & 1 & 0 & 0 & 0 & 0 \\
0 & 0 & 0 & 0 & 0 & 0 & 0 & 0 & -1
\end{array}\right]
$$

So, loss function (6) can be written as:

$$
\operatorname{LOSS}_{t}=Z_{t}^{\prime} K Z_{t}
$$

where $K$ is a $3 \times 3$ diagonal matrix, whose diagonal contains the preference parameters of the monetary authority $\left(\lambda_{\pi}, \lambda_{y}\right.$ and $\left.\lambda_{\Delta i}\right)$. Substituting Equation (11) into Equation (13), the loss function will then be:

$$
\begin{aligned}
& \operatorname{LOSS}_{t}=Z_{t}^{\prime} K Z_{t} \\
& \quad=\left[\begin{array}{ll}
X_{t}^{\prime} & i_{t}^{\prime}
\end{array}\right]\left[\begin{array}{c}
C_{x}^{\prime} \\
C_{i}^{\prime}
\end{array}\right] K\left[\begin{array}{ll}
C_{x} & C_{i}
\end{array}\right]\left[\begin{array}{c}
X_{t} \\
i_{t}
\end{array}\right] \\
& \quad=X_{t}^{\prime} C_{x}^{\prime} K C_{x} X_{t}+X_{t}^{\prime} C_{x}^{\prime} K C_{i} i_{t}+i_{t}^{\prime} C_{i}^{\prime} K C_{x} X_{t}+i_{t}^{\prime} C_{i}^{\prime} K C_{i} i_{t} \\
& \quad=X_{t}^{\prime} R X_{t}+X_{t}^{\prime} H_{i} i_{t}+i_{t}^{\prime} H X_{t}+i_{t}^{\prime} Q i_{t} \\
& \operatorname{LOSS}_{t}=X_{t}^{\prime} R X_{t}+i_{t}^{\prime} Q i_{t}+2 X_{t}^{\prime} H_{i} i_{t}
\end{aligned}
$$

where:

$$
R=C_{x}^{\prime} K C_{x} ; H=C_{x}^{\prime} K C_{i} ; Q=C_{i}^{\prime} K C_{i}
$$

Therefore, the central bank's control problem can be seen as an infinite-horizon stochastic linear regulator problem (Ljungqvist and Sargent, 2004), expressed by:

10 Vector $Z$, if the exchange rate is regarded as objective variable, is written as: $Z_{t}^{\prime}=\left[\begin{array}{llll}\pi^{a} & y_{t} & i_{t}-i_{t-1} & q_{t}-q_{t-1}\end{array}\right]$, where the procedure for derivation of the optimal monetary rule is the same in both cases. 
$\operatorname{MinE}_{0} \sum_{t=0}^{\infty} \beta^{t}\left[Z_{t}^{\prime} K Z_{t}\right]=\operatorname{Min}_{\left\{i_{t}\right\}_{t=0}^{\infty}} E_{0} \sum_{t=0}^{\infty} \beta^{t}\left[X_{t}^{\prime} R X_{t}+i_{t}^{\prime} Q i_{t}+2 X_{t}^{\prime} H i_{t}\right]$

Subject to the structure of the economy, given by:

$X_{t+1}=A X_{t}+B i_{t}+\xi_{t+1}$

where $X_{t}$ is a vector $(n x 1)$ of state variables, $i_{t}$ is the control variable of the monetary policy (nominal interest rate), $\mathrm{R}$ is a positive semidefinite symmetric matrix, $\mathrm{Q}$ is a positive definite symmetric matrix, $\mathrm{A}$ is an $(n x n)$ matrix and $\mathrm{B}$ is an $(n x 1)$ column matrix where $n$ stands for the number of state variables.

The solution to the problem in Equation (16) is based on a maximization process under the selection of $\left\{i_{t}\right\}_{t=0}^{\infty}$, but the equation must be rewritten. To do that, the loss function is made identical with the negative one and the "Certainty Equivalence Principle" is applied; the stochastic optimal regulator problem can be solved in the same way as the non-stochastic regulator problem. ${ }^{11}$ By applying the latter principle and using the transition law given by the structure of the economy to eliminate the state from the subsequent period, the stochastic linear regulator problem will be defined as:

$$
V\left(X_{t}\right)=\operatorname{Max}_{i}\left\{-X_{t}^{\prime} R X_{t}-i_{t}^{\prime} Q i_{t}-2 X_{t}^{\prime} H_{i} i-\left(A X_{t}+B i_{t}\right) P\left(A X_{t}+B i_{t}\right)\right\}
$$

The quadratic value function that satisfies Bellman's Equation (17) is given by: $V\left(X_{t}\right)=-X_{0} P X-d$, where $\mathrm{P}$ is a positive semidefinite symmetric matrix that satisfies the algebraic matrix Ricatti equation, $d$ is represented by $d=\beta(1-\beta)^{-1} \operatorname{tr} P \sum_{\xi \xi}$, where $\operatorname{tr}$ is the trace of matrix $\mathrm{P}$ and $\sum_{\xi \xi}$ is the covariance matrix of the disturbance vector $\xi_{t}$. Finally, $X_{0}$ is the initial vector of state variables as given. Then, using algebraic tools and deriving the first-order condition, it is possible to obtain the optimal monetary rule as follows: ${ }^{12}$

$$
V\left(X_{t}\right)=\underset{i}{\operatorname{Max}}-\left[X_{t}^{\prime} R X_{t}+i_{t}^{\prime} Q i_{t}+2 X_{t}^{\prime} H i\right]-\beta\left[X_{t}^{\prime} A^{\prime} P A X_{t}+X_{t}^{\prime} A^{\prime} P B i_{t}+i_{t}^{\prime} B^{\prime} P A X_{t}^{\prime}+i_{t}^{\prime} B^{\prime} P B i_{t}\right]
$$

11 For further details on this principle, see Ljungqvit and Sargent (2004, p.113-114).

12 For derivation of the optimal monetary rule, the following matrix derivation properties are used: $\frac{\partial\left(x^{\prime} A x\right)}{\partial x}=\left(A+A^{\prime}\right) x ; \frac{\partial\left(y^{\prime} B z\right)}{\partial y}=B z ; \frac{\partial\left(y^{\prime} B z\right)}{\partial z}=B^{\prime} y$ 


$$
\begin{aligned}
& V\left(X_{t}\right)=\operatorname{Max}_{i}-\left[X_{t}^{\prime} R X_{t}+i_{t}^{\prime} Q i_{t}+2 X_{t}^{\prime} H i_{t}\right]-\beta\left[X_{t}^{\prime} A^{\prime} P A X_{t}+2 X_{t}^{\prime} A^{\prime} P B i_{t}+i_{t}^{\prime} B^{\prime} P B i_{t}\right] \\
& -\left[2 Q i_{t}+2 H^{\prime} X_{t}+2 \beta\left(B^{\prime} P B i_{t}+B^{\prime} P A X_{t}\right)\right]=0 \\
& i_{t}=\underbrace{-\left(Q+\beta B^{\prime} P B\right)^{-1}\left(\beta B^{\prime} P A+H^{\prime}\right)}_{f} X_{t} \\
& i_{t}=f X_{t}
\end{aligned}
$$

Equation (20) shows that the derived optimal interest rate is a linear function of the economy's state variables, $X_{t}$ and of the linear vector, $f$, which contains convolutions of the monetary authority's preference parameters with the parameters of the Phillips and IS curves. Therefore, one may infer that, for different values of the parameters that represent the monetary authority's preferences, there is a distinct optimal monetary rule.

As soon as the optimal monetary rule has been obtained, the following step consists in checking that the solution effectively takes the form $V\left(X_{t}\right)=-X_{0} P X-d$, finding the matrix $P$ that satisfies the algebraic matrix Riccati. Substituting Equation (20) into (19), and after some algebraic development, matrix $\mathrm{P}$ will be written as:

$$
P=R+\beta A^{\prime} P A-\left(\beta A^{\prime} P B+H\right)\left(Q+\beta B^{\prime} P B\right)^{-1}\left(\beta B^{\prime} P A+H^{\prime}\right)
$$

Finally, substituting optimal monetary rule (20) into Equations (8) and (11) respectively, the dynamics of the model is determined by:

$$
\begin{aligned}
& X_{t+1}=M X_{t}+\xi_{t+1} \\
& Z_{t}=C X_{t}
\end{aligned}
$$

Where matrices $\mathrm{M}$ and $\mathrm{C}$ are given by:

$$
\begin{aligned}
& M=A+B f \\
& C=C_{X}+C_{i} f
\end{aligned}
$$




\subsection{Calibration Strategy for the Monetary Authority's Preferences}

For the identification of CRBP preferences from the feedback vector of coefficients, $f$, we use the calibration method based on the strategy followed by other authors for identifying the preferences of monetary authorities, among which we highlight the following: Castelnuevo and Surico (2003), Collins and Skilos (2004), Castelnuevo (2004) and Aragón and Portugal (2009), who consider the backward-looking behavior of economic agents.

As pointed out by Castelnuevo and Surico (2003), the calibration method has several advantages over conventional estimation methods, such as GMM and maximum likelihood. The first advantage is that this method does not rely on the distribution of the behavior of error terms present in the economic model that restricts the central bank's loss function. The second advantage is that this method facilitates the demonstration of the effects of the changes on calibrated parameters.

- Specifically, the calibration strategy we employed to identify CRBP preferences is split into four stages, as outlined next:

- The parameters that guide the structure of the Peruvian economy are estimated, represented by Equations (1)-(4). Thereafter, the obtained coefficients are inserted into the structure of the economy in their state-space form, system (6), which restricts the policymaker's intertemporal optimization problem;

- The coefficients of the optimal interest rate rule, obtained by solving the stochastic linear regulator problem, elaborated in the theoretical model, are calculated. Given that changes in the values of monetary authority's preferences imply different coefficients of the optimal monetary policy rule, the stochastic linear regulator problem was solved for a large set of preference values. Specifically, for a given preference value through interest rate smoothing $\lambda_{i}$, the optimal policy rule was calculated for every possible combination of $\lambda_{\pi}$ and $\lambda_{y}$ on the interval $\left[0.001-\left(1-\lambda_{i}-0.001\right)\right]$, with steps of $0.001 .{ }^{13}$ Preference parameter $\lambda_{i}$ is allowed to vary on the interval $[0-0.95]$ with steps of 0.05 ;

13 For the case in which interest rate smoothing $\lambda_{\Delta q}$ is considered, this smoothing varies on the interval $\left[0.001-\left(1-\lambda_{i}-0.001\right)\right]$. 
- Period by period, the values observed for state variables were substituted to calculate the optimal path for the interest rate in each optimal rule found in the combinations mentioned on the lines above;

- The preference values of the Peruvian monetary authority that minimize the squared deviation between the true path and the calculated optimal path are selected, that is:

$$
D Q=\sum_{t=1}^{T}\left[i_{t}-i\left(\lambda_{\pi}, \lambda_{y}, \lambda_{i}\right)\right]^{2}
$$

\section{Results}

\subsection{Results of the Macroeconomic Model Estimation for Peru}

As mentioned in the steps of the calibration strategy for the identification of the monetary authority's preferences, first it is necessary to estimate the macroeconomic model that restricts the CRBP's optimization process, given by the set of Equations (1)-(4). As the proposed model has backward-looking expectations, it would be subject to the Lucas critique (1976) about parameter instability. ${ }^{14}$ To overcome this problem, a single monetary regime was chosen, specifically the inflation targeting regime for the 1999:01-2008:02 period, with a quarterly frequency. Formally, the inflation targeting regime was implemented in Peru in 2002. However, 1999 was selected as the initial year for the present study because annual inflation has been lower than $5 \%$ and close to the tolerance interval set by the $\mathrm{CRBP}$ in the inflation targeting regime. The present sampling period ends in 2008:02, ${ }^{15}$ as the macroeconomic variables were influenced by the effects of the world financial crisis from the second half of 2008 onwards, ${ }^{16}$ especially by the reduction in the terms of trade caused by a slump in the price of metals. ${ }^{17}$

14 Ozlale (2003) and Rudebusch and Svensson (1999) found evidence that economic models with backward-looking expectations applied to the U.S. economy passed the parameter sta- bility tests (Andrews test and Wald statistic test), and were stable in several periods.

15 We also decided to end the sampling period at this time due to the presence of unit root in the time series of the terms of trade gap for periods after 2008:02.

16 In 2008, particularly from September on, the world financial crisis worsened, with the eventual bankruptcy of Lehman Brothers.

17 Peru is one of the major world exporters of metals, such as copper, gold, zinc, among others. 
The variables used are available from the CRBP website. They are defined as follows:

- Inflation rate $\left(\pi_{t}\right)$ : is the annualized quarterly inflation rate, measured by the consumer price index of the metropolitan region of Lima;

- Output gap $\left(y_{t}\right)$ : is the percentage difference between the quarterly seasonally adjusted real GDP, through X-Arimal2, and the potential output obtained by the Hodrick-Prescott filter;

- Nominal interest rate $\left(i_{t}\right)$ and real interest rate $\left(r_{t}\right)$ : variable $\left(i_{t}\right)$ is the annualized interbank nominal interest rate used as proxy for the monetary policy rate. ${ }^{18}$ Variable $\left(r_{t}\right)$ is obtained from the difference between the nominal interest rate $\left(i_{t}\right)$ and the inflation rate $\pi_{i}$;

- Terms of trade gap $\left(t t_{t}\right)$ : is the percentage difference between the terms of trade index with the respective potential obtained by the Hodrick-Prescott filter;

- Nominal exchange rate $\left(q_{t}\right)$ and nominal exchange rate depreciation $\left(\Delta q_{t}\right)$ : variable $q_{t}$ is calculated as: $100 \ln \left(Q_{t}\right)$ where $\ln$ denotes the natural logarithm and $Q_{t}$ is the quarterly mean of the monthly exchange rate, measured as the mean selling exchange rate for the period. Variable $\Delta q_{t}$ is the percentage variation in the nominal exchange rate.

After that, the stationarity of the series used was analyzed. To do that, we used the augmented Dickey-Fuller and the Phillips-Perron tests. The results shown in Table 1 demonstrate that the series are stationary, except for the exchange rate in which the unit root hypothesis cannot be rejected. However, exchange rate variation is stationary at a $1 \%$ significance level.

After implementation of the unit root tests, the macroeconomic model (1)-(4) was estimated. As the nominal exchange rate is assumed to follow a random walk, the estimation was based only on the IS curve equations, Phillips curve and terms of trade.

18 The CRBP announces the benchmark interest rate from 2001 on, within a band formed by the rediscount interest rate (upper bound) and the overnight rate (lower bound) which pays CRBP for private bank deposits. 
Two dummy variables were included in the IS curve equation. The first dummy, $d_{y, 1}(=1$ for 1999:04 and 0, otherwise), was inserted to capture the largest growth observed in domestic demand driven by increased private consumption in the fourth quarter of 1999. ${ }^{19}$ The second dummy, $d_{y, 2}(=1$ for 2002:02 and 0, otherwise), was inserted to capture the largest dynamism shown by the non-primary sector (specifically, the manufacturing and construction sectors), increase in credit lines in the financial sector and of microfinancing institutions in the private sector, and improvement in consumers' expectations, which stimulated economic activity in the second quarter of 2002.

Table 1- Results of the Unit Root Tests

\begin{tabular}{ccc}
\hline Variables & ADF & Phillips-Perron \\
\hline$y_{t}$ & $-1.809^{\mathrm{c}}$ & $-1.809^{\mathrm{b}}$ \\
$\pi_{t}^{+}$ & $-2.964^{\mathrm{c}}$ & $-3.234^{\mathrm{b}}$ \\
$r_{t}^{++}$ & $-5.59^{\mathrm{a}}$ & $-3.913^{\mathrm{b}}$ \\
$t t_{t}^{+}$ & $-2.774^{\mathrm{c}}$ & $-2.844^{\mathrm{c}}$ \\
$q_{t}^{++}$ & $-0.939^{\mathrm{n} .5}$ & $-1.983^{\mathrm{n} .5}$ \\
$\Delta q^{+}$ & $-3.923^{\mathrm{a}}$ & $-3.924^{\mathrm{a}}$ \\
\hline
\end{tabular}

Source: Obtained from the authors.

Notes: ${ }^{\text {a }}$ Significant at $1 \%,{ }^{\mathrm{b}}$ Significant at $5 \%,{ }^{\mathrm{c}}$ significant at $10 \%$,

${ }^{n s}$ Non-significant. The number of lags in all cases was 9, elected according to the Akaike information criterion.

+ Includes constant ++ Includes constant and trend.

Two dummy variables $d_{t t, 1}(=1$ for 2006:02 and 0, otherwise) and $d_{t t, 2}(=12007: 02$ and 0, otherwise) were added for the terms of trade equation in order to capture the large growth of the terms of trade due to an increase in export prices relative to import prices, corresponding to an increase in the price of metals such as copper, gold, zinc, among others. This increase was based on the heated economic growth of China, the major importer of Peru's raw materials. ${ }^{20}$

19 As registered by the Annual Report of BCRP (1999), this larger dynamism showed the end of the recession that Peru had been in due to the negative effects of the El Niño phenomenon and of the world financial crisis.

20 During 2007 China became the major purchaser of Peruvian mining products with a 39\% purchasing quota for both copper and gold (Anuário Minero- Peru, 2007). 
Finally, as mentioned in Section 3, we imposed verticality to the Phillips curve by the restriction that the sum of the inflation coefficients and the exchange rate variation should be equal to 1 . This implies that any exchange rate depreciation is totally transferred to prices in the long run.

That being said, the system to be estimated is formed by the following equations:

$$
\begin{aligned}
& \pi_{t}=\alpha_{1} \pi_{t-1}+\alpha_{2} \pi_{t-2}+\left(1-\alpha_{1}-\alpha_{2}-\alpha_{4}\right) \pi_{t-3}+\alpha_{4} \Delta q_{t-1}+\alpha_{5} y_{t-2}+\xi_{\pi} \\
& y_{t}=\beta_{1} y_{t-1}+\beta_{2} y_{t-2}+\beta_{3} r_{t-2}+\beta_{4} t t_{t-1}+\beta_{5} d_{y, 1}+\beta_{6} d_{y, 2}+\xi_{y, t+1} \\
& t t_{t}=\gamma_{1} t t_{t-1}+\gamma_{2} d_{t t, 1}+\gamma_{3} d_{t t, 2}+\xi_{t t, t+1}
\end{aligned}
$$

System (23)-(25) is estimated by two methods: 1) ordinary least squares (OLS); and 2) seemingly unrelated regressions (SUR). The latter method is the most appropriate when there exists a contemporaneous correlation between the error terms. In this case, the stronger the correlation between the errors, the larger the efficiency gain of the SUR estimator in relation to OLS. ${ }^{21}$

The parameters estimated for empirical model (23)-(25) are shown in Table 2. One may observe that, for both equations, the parameter estimates obtained by OLS are quite similar to those obtained by SUR.

The system had a better empirical fit for IS curve and terms of trade specifications, both amounting to 0.76 , compared to the Phillips curve, which corresponded to 0.35 , measured by $\mathrm{R}^{2}$. All the parameter estimates had the expected sign, but the second lag of inflation in the supply equation had a negative but statistically nonsignificant sign. The estimate of the parameter that measures the impact of exchange rate depreciation on inflation suggests that, ceteris paribus, a one-percentage-point increase in the nominal exchange rate depreciation at time $t$ leads to an increase of 0.41 percentage points in annualized inflation at time $t+l$. Note that the coefficient that measures the impact of the output gap on inflation is significant.

21 Note that the efficiency of the SUR estimator is guaranteed for sufficiently large samples, given that the smaller variability of the estimates is an asymptotic property. 
This result shows the key role of the output gap on inflation, acting as an important mechanism for the transmission of monetary policy, as pointed out in this study.

Table 2- Estimation Results for the Phillips and IS ${ }^{1}$ Curves

\begin{tabular}{|c|c|c|c|c|c|c|c|c|}
\hline \multicolumn{3}{|c|}{ Phillips curve } & \multicolumn{3}{|c|}{ IS curve } & \multicolumn{3}{|c|}{ Terms of trade curve } \\
\hline Parameters & OLS & SUR & Parameters & OLS & SUR & Parameters & OLS & SUR \\
\hline$\alpha_{1}$ & $\begin{array}{l}0.5839^{\mathrm{a}} \\
(0.1572)\end{array}$ & $\begin{array}{l}0.5702^{\mathrm{a}} \\
(0.1435)\end{array}$ & $\beta_{1}$ & $\begin{array}{l}1.0295^{\mathrm{a}} \\
(0.1517)\end{array}$ & $\begin{array}{l}1.0178^{\mathrm{a}} \\
(0.1329)\end{array}$ & $\gamma_{1}$ & $\begin{array}{l}0.7408^{\mathrm{a}} \\
(0.0912)\end{array}$ & $\begin{array}{l}0.7415^{a} \\
(0.0872)\end{array}$ \\
\hline$\alpha_{2}$ & $\begin{array}{c}-0.0391^{\text {ns }} \\
(0.1888)\end{array}$ & $\begin{array}{c}-0.0260^{\text {ns }} \\
(0.1730)\end{array}$ & $\beta_{2}$ & $\begin{array}{l}-0.2797^{\circ} \\
(0.1526)\end{array}$ & $\begin{array}{c}-0.2962^{b} \\
(0.1358)\end{array}$ & $\gamma_{2}$ & $\begin{array}{l}11.771^{\mathrm{a}} \\
(2.8537)\end{array}$ & $\begin{array}{l}11.551^{\mathrm{a}} \\
(2.7166)\end{array}$ \\
\hline$\alpha_{3}$ & 0.0456 & 0.0105 & $\beta_{3}$ & $\begin{array}{c}-0.0653^{n s} \\
(0.0432)\end{array}$ & $\begin{array}{c}-0.0407^{n \mathrm{~s}} \\
(0.0382)\end{array}$ & $\gamma_{3}$ & $\begin{array}{c}8.0182^{\mathrm{a}} \\
(2.8849)\end{array}$ & $\begin{array}{l}7.8169^{a} \\
(2.7462)\end{array}$ \\
\hline$\alpha_{4}$ & $\begin{array}{l}0.4096^{\mathrm{a}} \\
(0.1243)\end{array}$ & $\begin{array}{l}0.4453^{\mathrm{a}} \\
(0.1136)\end{array}$ & $\beta_{4}$ & $\begin{array}{l}0.0561^{d} \\
(0.0339)\end{array}$ & $\begin{array}{l}0.0550^{c} \\
(0.0298)\end{array}$ & & & \\
\hline \multirow[t]{2}{*}{$\alpha_{5}$} & $\begin{array}{l}0.3715^{c} \\
(0.2200)\end{array}$ & $\begin{array}{l}0.3761^{b} \\
(0.1781)\end{array}$ & $\beta_{5}$ & $\begin{array}{l}3.3175^{\mathrm{a}} \\
(1.0730)\end{array}$ & $\begin{array}{l}2.8022^{\mathrm{a}} \\
(0.9422)\end{array}$ & & & \\
\hline & & & $\beta_{6}$ & $\begin{array}{l}2.4195^{b} \\
(1.0642)\end{array}$ & $\begin{array}{l}2.4592^{\mathrm{a}} \\
(0.9332)\end{array}$ & & & \\
\hline $\mathrm{R}^{2}$ & 0.3488 & 0.3465 & $\mathrm{R}^{2}$ & 0.7551 & 0.7504 & $\mathrm{R}^{2}$ & 0.7590 & 0.7589 \\
\hline \multicolumn{9}{|c|}{ Diagnostic test (p-values) } \\
\hline$Q(4)$ & 0.6331 & 0.5861 & $Q(4)$ & 0.8770 & 0.8264 & $\mathrm{Q}(4)$ & 0.2761 & 0.2657 \\
\hline$Q(6)$ & 0.7612 & 0.7079 & $Q(6)$ & 0.9252 & 0.8011 & $Q(6)$ & 0.2248 & 0.2167 \\
\hline $\mathrm{ARCH}(4)$ & 0.6269 & 0.6165 & $\mathrm{ARCH}(4)$ & 0.2196 & 0.2103 & $\mathrm{ARCH}(4)$ & 0.6438 & 0.6447 \\
\hline $\mathrm{JB}$ & 0.4901 & 0.4854 & $J B$ & 0.3836 & 0.4463 & $J B$ & 0.6229 & 0.6261 \\
\hline
\end{tabular}

Source: Obtained from the authors.

Notes: ${ }^{a}$ Significant at $1 \%,{ }^{b}$ Significant at $5 \%,{ }^{c}$ significant at $10 \%,{ }^{d}$ significant at $11 \%$, ${ }^{\text {ns }}$ Nonsignificant.

${ }^{1}$ Standard deviation value is between parentheses.

With regard to the IS curve equation, the lag coefficients of the output gap and of the terms of trade lagged one period were statistically significant (see Table 2). On the other hand, the coefficient of the real interest rate was not statistically significant. Even though this result suggests a minor initial role of monetary policy, the impact of the lagged values of the output gap on the IS curve is remarkable, implying that the response of the aggregate demand to the monetary policy rate is larger in the long run. ${ }^{22}$

According to the specifications of the Phillips and IS curves contemplated herein, the effect of the monetary policy interest rate on inflation is indirect and takes four quarters to fully operate. Based on OLS estimations, an increase of one percentage point in the real interest rate at time $t$ reduces the output gap by 0.0653 percentage points at time $t+2$. In turn, a reduction in the output gap reduces

22 Similar results were obtained by Castelnuevo and Surico (2003) for the USA. 
inflation by 0.3715 percentage points after two periods. Therefore, an increase in the real interest rate of one percentage point at time $t$ causes a reduction of 0.02 percentage points in the inflation rate at $t+4$. However, these results should be viewed with caution due to the statistical non-significance of the real interest rate coefficient in the IS curve equation.

Another result that is noteworthy concerns the effect of the terms of trade gap on the output gap. The evidence shows a positive correlation between these two variables, with the coefficient statistically significant at $11 \%$. This suggests that, ceterus paribus, an increase of one percentage point in the terms of trade gap, produced by a rise in export prices (or a decrease in import prices), increases the output gap by approximately 0.0561 percentage points in the subsequent period.

With respect to the terms of trade equation, the autoregressive coefficient and the two dummy variables were statistically significant.

Additionally, tests were run to detect the presence of problems with autocorrelation, conditional heteroskedasticity and non-normality in the error terms of system (23)-(25). To this end, Q tests of LjungBox (LB), the ARCH effect and the Jarque-Bera test were used, respectively. The results demonstrate absence of autocorrelation and of conditional heteroskedasticity for system errors. On the other hand, the JB test showed that the residuals of the three equations are normally distributed (see Table 2).

\subsection{Calibration of CRBP Preferences in the Inflation Targeting Regime}

Once the parameters that determine the economic structure were obtained, the following step consisted in identifying the CRBP preferences. To accomplish that, we chose the weights that determine the monetary authority's preferences for inflation and output stabilization and interest rate smoothing in the loss function of the central bank that minimizes the squared deviation between the actual interest rate and the optimal interest rate. The optimal interest rate is derived based on the true history of the economy at each time point, i.e., by substituting the vector of state variables in every period following the optimal monetary policy rule. 
The OLS estimates ${ }^{23}$ of the macroeconomic model were chosen to start the calibration process. Following Aragón and Portugal (2009), the objective discount factor, $\delta$, is assumed to be $0.98 .^{24} \mathrm{On}$ the other hand, as pointed out in the third step of the calibration process, for each value of $\lambda_{\Delta i}$, the optimal monetary rule is calculated for every possible combination of $\lambda_{\pi}$ and $\lambda_{y}$ on the interval $\left[0.001-\left(1-\lambda_{\Delta i}-0.001\right)\right]$, with steps of 0.001 . This calibration strategy allows obtaining 10,480 monetary policy rules and choosing the loss function parameters that minimize the squared deviation between the optimal and true interest rate path.

The calibrated parameters of the central bank's loss function are shown in Table 3, where the respective weights for $\lambda_{\pi}$ and $\lambda_{y}$ which result in smaller squared deviation (SD) correspond to each value of $\lambda_{\Delta i}$. Initially, a zero weight on interest rate smoothing produces a very large squared deviation. This result evidences that the monetary authority must have attributed a positive weight to interest rate smoothing in its loss function.

The results show that, when the central bank's preference is increased by interest rate smoothing, specifically from the interval 0.05 to 0.40 , preference for inflation stability tends to grow, whereas preference for output stability tends to be mild or negligible $\left(\lambda_{y}=\right.$ $0.00)$. The opposite is observed for weights on interest rate smoothing greater than 0.50 . For instance, for $\lambda_{\Delta i}=0.60$, the weight for inflation is virtually equal to 0.00 , while the weight for the output gap is virtually equal to 0.40 . Conversely, for interest rate smoothing weights greater than 0.80 , the monetary authority is more concerned with the gradualist approach to the interest rate than with inflation and output stability around their targets.

Table 3 indicates that the parameters that minimize the squared deviation between the observed interest rate path and the optimal interest rate are $\lambda_{\pi}=0.699, \lambda_{y}=0.001$ and $\lambda_{\Delta i}=0.30$. These results reveal that the CRBP has adopted a flexible inflation targeting regime, placing a larger weight on inflation stability followed by interest rate smoothing and, finally, on output stability. These results are

23 The estimates obtained by SUR did not show large differences from those obtained by OLS and did not change the calibration results. These results are available from the authors upon request.

24 For different discount factor $(\delta)$ values, there is no change in the identification of preferences. These results are available from the authors upon request. 
relevant because they are consistent with the actions taken by the monetary authority during the current inflation targeting.

Table 3 - Central Bank's Loss Function Estimated Parameters

\begin{tabular}{|c|c|c|c|}
\hline$\lambda_{\Delta i}$ & $\lambda_{\pi}$ & $\lambda_{y}$ & Squared deviation (SD) \\
\hline 0.00 & 0.001 & 0.999 & $13,558.01$ \\
\hline 0.05 & 0.949 & 0.001 & 299.29 \\
\hline 0.10 & 0.899 & 0.001 & 199.99 \\
\hline 0.15 & 0.849 & 0.001 & 174.64 \\
\hline 0.20 & 0.799 & 0.001 & 165.58 \\
\hline 0.25 & 0.749 & 0.001 & 162.25 \\
\hline 0.30 & 0.699 & 0.001 & 161.43 \\
\hline 0.35 & 0.649 & 0.001 & 161.85 \\
\hline 0.40 & 0.599 & 0.001 & 162.95 \\
\hline 0.45 & 0.435 & 0.115 & 164.38 \\
\hline 0.50 & 0.217 & 0.283 & 165.82 \\
\hline 0.55 & 0.001 & 0.449 & 167.20 \\
\hline 0.60 & 0.001 & 0.399 & 168.73 \\
\hline 0.65 & 0.001 & 0.349 & 170.53 \\
\hline 0.70 & 0.001 & 0.299 & 172.59 \\
\hline 0.75 & 0.001 & 0.249 & 174.94 \\
\hline 0.80 & 0.001 & 0.199 & 177.61 \\
\hline 0.85 & 0.001 & 0.149 & 180.72 \\
\hline 0.90 & 0.001 & 0.099 & 184.51 \\
\hline 0.95 & 0.001 & 0.049 & 189.64 \\
\hline
\end{tabular}

Source: Obtained from the authors.

Observe that the weight on output stabilization around its potential value is an interesting result. This may not have been an ultimate concern of the monetary authority in the inflation targeting regime $\left(\lambda_{y}=0.001\right)$. Despite the low weight of output gap on the central bank's loss function, its insertion into the model is important as this variable is key to generating information on the behavior of future inflation (Dennis, 2006).

On the other hand, a weight of 0.30 on interest rate smoothing shows the importance that the Peruvian monetary authority has attached to the gradualist approach to the interest rate in the inflation targeting regime as response to inflation flexibility, mainly from 2002 onwards, when interest rate movements were directed toward stabilizing inflation and maintaining preventive actions in order to 
sustain economic agents' inflation expectations (MEMORIA BCRP, 2002).

An interesting second exercise to be considered in the calibration process consists in knowing whether the CRBP has demonstrated any preference for nominal exchange rate smoothing, as in the study period, the Peruvian monetary authority made important interventions in the exchange rate market. ${ }^{25}$ In addition, it also serves to check whether the order of preferences of the monetary authority for inflation and output stability and interest rate smoothing remains robust to the inclusion of exchange rate smoothing in the loss function.

Table 4 - Central Bank's Loss Function Estimated Parameters Including Preference for Exchange Rate Smoothing

\begin{tabular}{ccccc}
\hline$\lambda_{\Delta i}$ & $\lambda_{\pi}$ & $\lambda_{y}$ & $\lambda_{\Delta q}$ & $\begin{array}{c}\text { Squared deviation } \\
\text { (SD) }\end{array}$ \\
\hline 0.00 & 0.01 & 0.98 & 0.01 & $13,628.87$ \\
0.05 & 0.10 & 0.01 & 0.84 & 161.741 \\
0.10 & 0.22 & 0.01 & 0.67 & 161.574 \\
0.15 & 0.33 & 0.01 & 0.51 & 161.521 \\
0.20 & 0.45 & 0.01 & 0.34 & 161.495 \\
0.25 & 0.56 & 0.01 & 0.18 & 161.480 \\
0.30 & 0.68 & 0.01 & 0.01 & 161.470 \\
0.35 & 0.63 & 0.01 & 0.01 & 161.931 \\
0.40 & 0.58 & 0.01 & 0.01 & 163.065 \\
0.45 & 0.41 & 0.13 & 0.01 & 164.515 \\
0.50 & 0.19 & 0.30 & 0.01 & 165.965 \\
0.55 & 0.01 & 0.43 & 0.01 & 167.3612 \\
0.60 & 0.01 & 0.38 & 0.01 & 168.9489 \\
0.65 & 0.01 & 0.33 & 0.01 & 170.8191 \\
0.70 & 0.01 & 0.28 & 0.01 & 172.9603 \\
0.75 & 0.01 & 0.23 & 0.01 & 175.3927 \\
0.80 & 0.01 & 0.18 & 0.01 & 178.1771 \\
0.85 & 0.01 & 0.13 & 0.01 & 181.4453 \\
0.90 & 0.01 & 0.08 & 0.01 & 185.4966 \\
0.95 & 0.01 & 0.03 & 0.01 & 191.2529 \\
\hline
\end{tabular}

Source: Obtained from the authors.

25 The justifications for considering this exercisewere addressed in Section 2 of the present paper. 
The results found for this second case are shown in Table 4 and reveal that the order of preference for inflation and interest rate smoothing has been maintained, with weights of $\lambda_{\pi}=0.68$ and $\lambda_{\Delta i}=0.30$, respectively. However, the preferences for exchange rate smoothing and output gap stabilization were non-significant, both with a weight equal to 0.01 . These results suggest that: i) exchange rate smoothing has not played an important role in the CRBP's loss function; ii) Exchange rate market interventions made by the Peruvian monetary authority were consistent with the current inflation targeting regime, precluding any conflict of objectives that could undermine the monetary authority's credibility, which is absolutely necessary to sustain inflation expectations.

\subsubsection{Optimal Monetary Policy Rule}

According to the calibration strategy, the estimated parameters of the macroeconomic model and of the identification of preferences in the loss function imply that the optimal monetary rule, mentioned in Equation (20), is given by:

$$
\begin{aligned}
& i_{t}=0.107 \pi_{t}+0.028 \pi_{t-1}+0.006 \pi_{t-2}+0.000 \pi_{t-3}+ \\
& 0.346 y_{t}-0.062 y_{t-1}+0.053 \Delta q_{t}+0.082 t t_{t}+0.763 i_{t-1}
\end{aligned}
$$

This monetary rule implies that the Peruvian monetary authority responds contemporaneously to inflation rate movements, output gap, terms of trade gap and nominal exchange rate fluctuations. The coefficients of each variable in the monetary rule can be construed as the percentage variation in the interest rate due to a $1 \%$ change in the respective explanatory variable. Thus, an increase of one percentage point in the inflation rate drives the interest rate up by 0.11 percentage points; an increase of one percentage point in the output gap causes the interest rate to grow by 0.35 percentage points; an increase of one percentage point in exchange rate depreciation raises the interest rate by approximately 0.05 percentage points and an increase of one percentage point in the terms of trade gap pushes the interest rate up by 0.08 percentage points. The Peruvian monetary authority also responds to the lagged values of the inflation rate (two lags) and of the output gap, although this response is smaller than contemporaneous inflation and output gap values. Another important result concerns the dependence of interest rate lags, which 
amounted to approximately 0.76 . This result reflects the Peruvian monetary authority's concern with interest rate smoothing.

The coefficients of the optimal monetary policy rule (30) represent the immediate effect of explanatory variables on interest rates. Nevertheless, state variables also have secondary effects on the interest rate as a result of their lagged values and of the inertial term $i_{t-1}$. These secondary effects can be measured by expressing the optimal monetary policy rule in the long run, given by:

$$
\begin{aligned}
& i=\theta_{1} \pi+\theta_{2} y+\theta_{3} \Delta q+\theta_{4} t t \\
& i=0.595 \pi+1.199 y+0.225 \Delta q+0.346 t t
\end{aligned}
$$

where $\theta_{1}=\left(f_{1}+f_{2}+f_{3}+f_{4}\right) /\left(1-f_{10}\right), \theta_{2}=\left(f_{5}+f_{6}\right) /\left(1-f_{10}\right)$,

$$
\theta_{3}=f_{7} /\left(1-f_{10}\right), \theta_{4}=f_{9} /\left(1-f_{10}\right) \text {. }
$$

The results indicate that the long-term monetary rule responds strongly to the output gap, i.e., an increase of one percentage point in the output gap raises the interest rate by 1.199 percentage points, revealing a procyclical behavior towards the output gap. However, an increase of one percentage point in the inflation rate pushes the interest rate up by 0.595 percentage points. The latter result shows that the Taylor $(1993,1998)$ principle is not satisfied. Notwithstanding, this result should be viewed with caution given that, in the case of a small open economy like that of Peru, other important variables in addition to output and inflation are taken into account in establishing the monetary rule (such as terms of trade and exchange rate depreciation). Furthermore, these two variables are correlated with inflation, and through its indirect effects, they eventually influence inflation rate movements. Therefore, not only can the effects of inflation on the interest rate be seen straightforwardly, that is, through contemporaneous inflation, but also indirectly through the terms of trade and exchange rate depreciation. On the other hand, similar results were obtained in other studies, as the ones conducted by Leiderman et al. (2006) and Quezada (2004). 


\subsubsection{Optimal Path versus Observed Interest Rate Path}

Figure 1 shows the path for the optimal interest rate associated with the preferences obtained by the calibration strategy and the true interest rate path approximated by the interbank rate. ${ }^{26}$ Note that the optimal interest rate captures the main movements of the observed interest rate. However, there are some inconsistencies, especially in the first periods. For instance, the monetary authority with calibrated weights may have maintained the interest rate lower than the observed interest rate for the second and fourth quarters of year 2000 (period strongly influenced by uncertainty over the presidential elections) in response to lower expectations of exchange rate depreciation and inflation during that period.

On the other hand, the developments of the electoral year in 2000 exerted a strong impact on financial variables in 2001, chiefly during the second half of 2001 when the interest rate went up from 11 to 14 percentage points. Nevertheless, Figure 1 shows that the monetary authority with an optimal behavior could have pushed the interest rate down to around 9 percentage points during the second quarter of 2001.

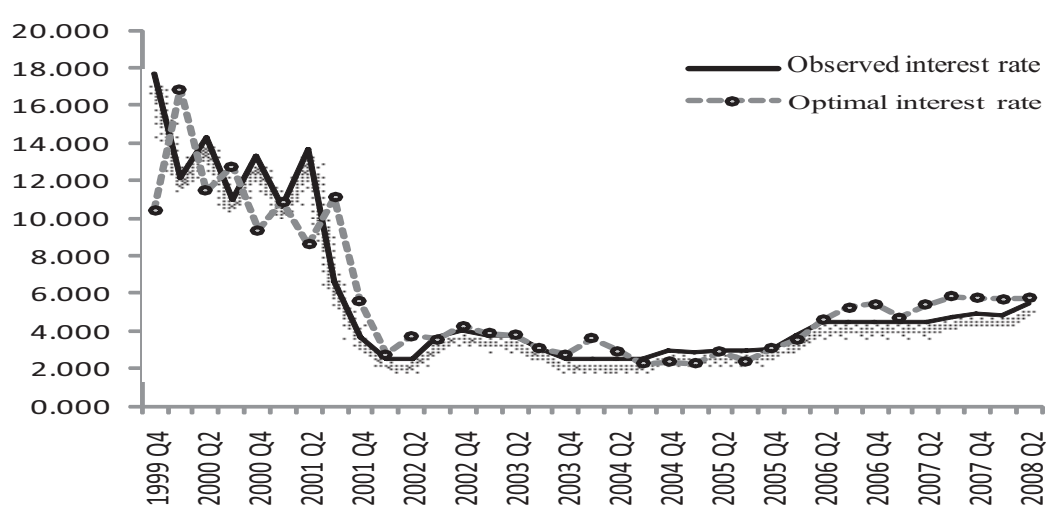

Figure 1 - Observed Interest Rate versus Optimal Interest Rate

Another important difference arises between the second half of 2001 to the first half of 2002, when the monetary authority could

26 This Figure shows the path for the optimal interest rate obtained by calibration without considering a weight for exchange rate smoothing given that, when this variable is added to the analysis, the results do not differ remarkably. 
have adopted an expansionary behavior to keep tabs on the marked deceleration of the inflation rate in that period. However, it is important to note that the observed interest rate increased at a slower pace than did the interest rate predicted by the optimal rule associated with calibrated weights.

Finally, after 2002, the optimal path for the interest rate was very close to that of the observed interest rate. Despite that, some minor inconsistencies can be encountered after the second quarter of 2006, when the optimal interest rate is above the observed interest rate, reaching a maximum difference of 104 basis points in the third quarter of 2007. This piece of evidence suggests that the monetary authority with an optimal behavior could have maintained a more contractionary monetary policy in order to overcome the adverse outcomes of the macroeconomic environment, brought about by the strong dynamism of domestic demand and of substantial increases in international prices (food and fuel), which ended up producing inflationary pressures.

\subsubsection{Comparison with Alternative Weights on the Loss Function}

Another important analysis for the identification of central bank's preferences includes the comparison of the optimal monetary policy rule derived from calibrated weights with monetary rules related to other weights. To do that, four different sets of weights were considered, in addition to those obtained from the calibration process (see Table 5).

The first set of weights shows the case of a strict inflation target. In other words, the central bank is only concerned with stabilizing inflation (King, 1997). In the second case, weights for flexible inflation targets are considered, especially those used by Rudebusch and Svensson (1999) in which the central bank equally weighs the weights for stabilization of inflation and output with some degree of interest rate smoothing. The third case concerns the set of weights obtained by the calibration strategy. In the fourth and fifth cases, Benchmarkl and Benchmark2, the importance given by the monetary authority to interest rate smoothing of its loss function is taken into consideration. Therefore, in the fourth case, a zero 
weight was used for interest rate smoothing and equal weights for the stabilization of inflation and output. The fifth case encompasses combinations of $\left\{\lambda_{\pi}, \lambda_{y}\right\}$ which minimize the squared deviation of the observed interest rate from the optimal interest rate for values of $\lambda_{\Delta i}$ equal to $0.90 .{ }^{27}$

Table 5 - Weights Used in the CRBP's Loss Function

\begin{tabular}{clccc}
\hline \multicolumn{1}{c}{ Cases } & $\lambda_{\pi}$ & $\lambda_{y}$ & $\lambda_{i}$ \\
\hline 1. & Strict inflation targets (King, 1997) & 1.0 & 0.0 & 0.0 \\
2. & Flexible inflation targets ( Rudebusch and Svensson, 1999) & 0.4 & 0.4 & 0.2 \\
3. & Calibrated weights & 0.699 & 0.001 & 0.30 \\
4. & Bechmark 1 & 0.5 & 0.5 & 0.0 \\
5. & Bechmark 2 & 0.001 & 0.099 & 0.90 \\
\hline
\end{tabular}

Source: Obtained from the authors.

The respective optimal monetary rule was obtained for each set of alternative weights included in the central bank's loss function. Thus, as shown in Table 6, in the cases in which a zero weight is used for interest rate smoothing (cases 1 and 4), the coefficients obtained for the optimal rules and the squared deviation had high values compared to those obtained by calibration (case 3). This result suggests that the Peruvian monetary authority used a positive weight for interest rate smoothing.

${ }^{27}$ Dennis (2006) and Ozlale (2003) argued that optimal monetary rules provide better fit of the interest rate path in backward-looking models if the monetary authority smooths the interest rate (evidence for the USA). 
Table 6 - Short-and Long-Term Optimal Monetary Rules for Different Weights on the CRBP's Loss Function

\begin{tabular}{|c|c|c|c|c|c|}
\hline & Case 1 & Case 2 & Case 3 & Case 4 & Case 5 \\
\hline \multicolumn{6}{|c|}{ Short-term optimal monetary rule } \\
\hline$f_{1}$ & 51.141 & 0.142 & 0.107 & 2.170 & 0.011 \\
\hline$f_{2}$ & 2.793 & 0.044 & 0.028 & 1.158 & 0.003 \\
\hline$f_{3}$ & 3.917 & 0.007 & 0.006 & 0.088 & 0.001 \\
\hline$f_{4}$ & 0.000 & 0.000 & 0.000 & 0.000 & 0.000 \\
\hline$f_{5}$ & 65.837 & 0.515 & 0.346 & 14.233 & 0.039 \\
\hline$f_{6}$ & 20.741 & -0.128 & -0.062 & -4.043 & -0.010 \\
\hline$f_{7}$ & 35.222 & 0.062 & 0.053 & 0.789 & 0.005 \\
\hline$f_{8}$ & 2.885 & 0.135 & 0.082 & 1.592 & 0.014 \\
\hline$f_{9}$ & -2.613 & 0.677 & 0.763 & -1.110 & 0.920 \\
\hline$D Q$ & 1. $703 \mathrm{E}+06$ & 171.97 & 161.43 & 21263.00 & 184.512 \\
\hline \multicolumn{6}{|c|}{ Long-term optimal monetary rule } \\
\hline$\theta_{1}$ & 16.010 & 0.600 & 0.595 & 1.619 & 0.191 \\
\hline$\theta_{2}$ & 23.960 & 1.197 & 1.199 & 4.829 & 0.360 \\
\hline$\theta_{3}$ & 9.748 & 0.192 & 0.225 & 0.374 & 0.061 \\
\hline$\theta_{4}$ & 0.798 & 0.417 & 0.346 & 0.754 & 0.177 \\
\hline
\end{tabular}

Source: Obtained from the authors.

For the set of weights corresponding to the flexible inflation target (case 2), the coefficients of the short- and long-term monetary policy rules had values very close to those found for the optimal monetary rule derived from the calibration process. Notwithstanding, the squared deviation in case 2 was larger than in case 3 . This suggests that the Peruvian monetary authority has come quite close to the application of the flexible inflation targets.

In the case in which a larger weight was used for interest rate smoothing (case 5), the coefficient for gradualist approach to the interest rate in the short-term optimal monetary rule had a higher value than in case 3. This implies that a higher preference for interest rate smoothing leads to larger gradualism by the monetary authority, but with a larger squared deviation between the observed interest rate and the optimal interest rate. Another way to present the differences between the alternative weights and the calibrated ones is to do that visually. Figure 2 shows the optimal paths for the monetary policy rules derived from each of the cases analyzed. 
Case 1: Strict inflation target

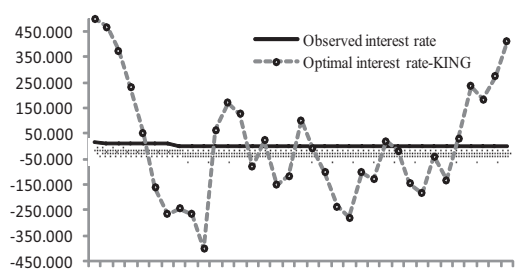

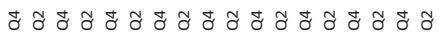

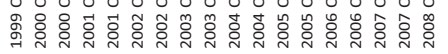

Case 3: Calibrated weights

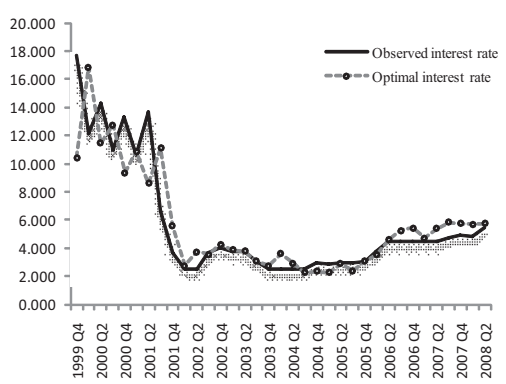

Case 2: Flexible inflation target

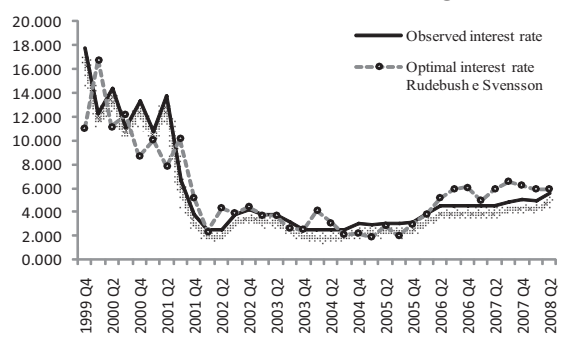

Case 4: Benchmark 1

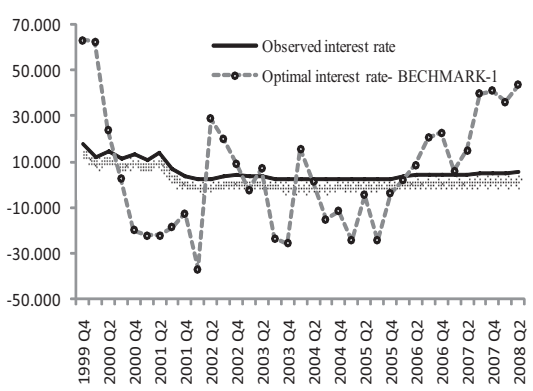

Case 5: Benchmark 2

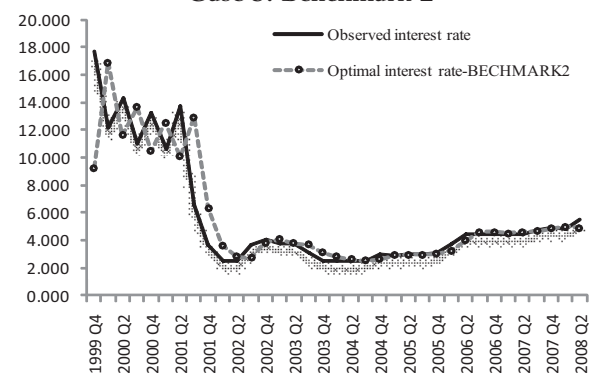

Figure 2 - Observed Interest Rate versus Optimal Interest Rate

As shown in Figure 2, the optimal path for the strict inflation targets (case 1) and the path for the optimal monetary rule when a zero weight is used for inflation smoothing (case 4) exhibit large inconsistencies relative to the true path for the interest rate, producing positive and negative values with up to three digits. ${ }^{28}$ This demonstrates that the Peruvian monetary authority has neither followed a strict inflation targeting regime nor used a zero weight for interest

${ }^{28}$ No imposition of non-negativity of the nominal interest rate is considered. 
rate smoothing. Also, the optimal path with a positive weight for interest rate smoothing (cases 2 and 5) seems to follow a path that is pretty close to the true path for the interest rate. However, some inconsistencies can be highlighted. In case 2, in which flexible inflation targets are considered, the optimal monetary rule varies more than the true interest rate path, with a difference of approximately 145 points in the third quarter of 2006. Moreover, when the weight on interest rate smoothing is increased, the optimal monetary rule path has more lags in relation to a reduction in inflation, especially in the last two quarters of 2001.

Although the visual inspection of the different paths for the optimal monetary rules is informative, it is not necessarily conclusive, and more formal tests should therefore be used. To circumvent this problem, the encompassing test proposed by Chong and Hendry (1986) is applied. More specifically, this test compares the optimal monetary rule derived from calibrated weights with other monetary rules derived from other alternative weights. Here the purpose is to decide whether the former predominates statistically over the others, i.e., if the optimal monetary rule of the calibrated weights explains the path of the true interest rate in a more appropriate fashion. This test originates from a regression as follows: $i_{t}=\varpi_{1} i_{t}^{*}+\varpi_{2} i_{t}^{* *}+\varepsilon_{t}$, where $i_{t}^{*}$ is the interest rate predicted by calibrated weights and $i_{t}^{* *}$ is the interest rate predicted by the opposing case. To make a distinction between $i_{t}^{*}$ and $i_{t}^{* *}$, Wald statistic test is applied as follows: $H^{*}: \varpi_{1}=1, \varpi_{2}=0$ or $H^{* * t}: \varpi_{1}=0, \varpi_{2}=1$. If $H^{*}$ is not rejected, but $H^{* *}$ is, then one may say that $i_{t}^{*}$ predominates over the interest rate predicted by the opposing weights, $i_{t}^{* *}$ (and vice versa).

Table 7 - Comparison Test for Different Optimal Monetary Rules: Case 3 versus other Cases

\begin{tabular}{lcc}
\hline \multicolumn{1}{c}{ Cases } & $\mathbf{H}^{\star}$ & $\mathbf{H}^{\star \star}$ \\
\hline Calibrated weights versus strict target $\pi$ & 0.1767 & 175896.30 \\
& $(0.8388)$ & $(0.0000)$ \\
Calibrated weights versus flexible target $\pi$ & 0.0423 & 1.1223 \\
& $(0.9587)$ & $(0.3376)$ \\
Calibrated weights versus Bechmark 1 & 0.0438 & 2162.65 \\
& $(0.9572)$ & $(0.0000)$ \\
Calibrated weights versus Bechmark 2 & 0.0063 & 2.3669 \\
& $(0.9937)$ & $(0.1095)$ \\
\hline
\end{tabular}

Source: Obtained from the authors.

Note: P-values are between parentheses. A lower p-value indicates that the null hypothesis is rejected. 
The results for the encompassing test (Table 7) confirm the results presented in Figure 2. The weights of a strict inflation target are easily eliminated because they are dominated by calibrated weights. On the other hand, the test confirms what has been found visually: the monetary authority did not use a zero weight for interest rate smoothing on the loss function (Bechmark 1). When calibrated weights are compared with that of the central bank, which attached more weight upon interest rate smoothing, dominance is only observed at a significance level greater than $11 \%$. However, the dominance of calibrated weights over those used for the flexible inflation rates (Svensson and Rudebusch (1999) is only considered at a significance level greater than 34\%. As seen in the latter two cases, there does not seem to be clear dominance of calibrated weights. Nevertheless, using the squared deviation obtained from the calibration exercise, it is possible to conclude that the CRBP conducted a monetary policy by giving preference to inflation stabilization, followed by considerable preference for interest rate smoothing and, to a lesser extent, for output stability.

\section{Conclusions}

Growing empirical evidence in the past two decades has shown improved efficiency of monetary policy in several countries, specifically in those that have adopted the inflation targeting regime. Peru has formally used the inflation targeting regime since 2002, a decision that was made by the monetary authority after a significant reduction in the growth of price level in the 1990s. Therefore, monetary base has been put aside as a monetary policy instrument, and an interest rate announcement policy has been used instead. Under this new regime, the monetary authority, in addition to a clear period of price stability with public announcements of a numerical inflation target, is in general less explicit with regard to other political goals, which are driven by its preferences.

As the coefficients of monetary rules are convolutions of the monetary authority's preferences and of the economic parameters, the present study aimed to identify the CRBP's preferences using a calibration process. To do that, it was assumed that the monetary authority solves an optimization problem restricted to the economic structure with backward-looking expectations. After that, the 
monetary authority's loss function was calibrated by choosing from a large class of policy alternatives, parameter values of preferences that minimize the squared deviation between the true interest rate path and the simulated interest rate.

The performed calibration showed that the Peruvian monetary authority during the inflation targeting regime can be effectively described by a flexible inflation targeting policy, giving priority to inflation stabilization without overlooking the interest rate movements which, since 2002, have been directed towards stabilizing inflation. On the other hand, the concern with output stabilization has been minimal, revealing that the output gap is important because it contains information about future inflation and not because it is considered as a target variable itself. Finally, when nominal exchange rate smoothing is added to the monetary authority's loss function, the order of preferences has been maintained, although exchange rate smoothing has had a negligible weight. This latter result has been consistent with the inflation targeting regime adopted by Peru, precluding any conflict of objectives that eventually undermine the monetary authority's credibility, which is absolutely necessary to sustain inflationary expectations.

The results found here can be compared with those obtained for Brazil by Aragón e Portugal (2009), since the methodology used to estimate the Central Bank Preferences in both cases is similar. ${ }^{29}$ The preference parameters found by Aragón e Portugal (2009) for the Central bank of Brazil were: $\lambda_{\pi}=0.727, \lambda_{y}=0.073$ e $\lambda_{\Delta i}=0.2$. Those were the weights that minimize the quadratic deviations between the optimal monetary policy and the actual monetary policy instrument (Selic).

In both cases (Peru and Brazil) the bigger weight is given to de inflation gap, followed by the output gap and interest rate smoothing. Nevertheless some differences arise. First, the value of the inflation gap $\left(\lambda_{\pi}\right)$ weight is much bigger in Brazil. It means that the Central Bank of Brazil is more inflation averse than the Central Bank of Peru. This result may be due to the strong macroeconomic instability faced by Brazilian economy during the estimation period.

29 Aragón e Portugal (2009) also uses a backward-looking macro model with quarterly data (from 1999-1 until 2007-3) to estimate the preferences of the Central Bank of Brasil. Both Brazil and Peru are developing economies that use inflation targeting. 
The Brazilian presidential elections of 2002, for example, imposed a strong challenge to the Central Bank. In this context is reasonably to suppose that the Central Bank would look more averse to inflation.

Secondly, the CRBP gives more weight inflation soothing $\left(\lambda_{\Delta i}\right)$ and less weight the output gap $\left(\lambda_{y}\right)$ than Brazil. We believe that the degree of commercial and financial integration may be in the root of these differences. The Peruvian economy is more open that the Brazilian economy, therefore interest rate volatility can cause unwanted volatility in the exchange rate and instability in the financial sector, implying that the CRBP should give more weight to interest rate smoothing than the central Bank of Brazil. On the other hand, the higher degree of commercial openness may also imply that Peruvian output is more sensitive to external variables, such as the world output, that are out of reach for the CRBP.

Finally, the quadratic deviations between the actual and optimal monetary policy is grater in Peru (4.48 percent points) than in Brazil (1.73 percent points). It means that actual monetary policy decisions in Brazil have been closer to the optimal ones.

\section{References}

Aragón, E. K. da S. B.; Portugal, M. S. Central Bank Preferences and Monetary Rules under the Inflation Targeting Regime in Brazil. Brazilian Review of Econometrics, v. 29, n. 1, 2009.

BANCO CENTRAL DO RESERVA DO PERU. Reportes de Inflación: Panorama Actual y Proyecciones (2002-2009). Disponível em: <www.bcrp.gob.pe/publicaciones >. Acesso em: 04 de abr. 2009.

BANCO CENTRAL DO RESERVA DO PERU. Memorias Anuales del Banco Central.1991-2007. Disponível em: http://www.bcrp.gob.pe/publicaciones/memoria-anual.html Acesso em: 04 de Abril. 2009.

Bejarano,W.B. Algumas lecciones y preferências reveladas de la Política Monetária del Perú em la última década. Documento de Trabajo, Banco Central de Reserva del Peru, n. 14, 2001. Disponível em: $<$ http://www.bcrp.gob.pe/docs/publicaciones/Documentos-de-trabajo/2001/Documento-trabajo02-2001.pdf. >Acesso em: 15 de Abr. 2009.

Castelnuevo, E.; Surico, P. What does monetary policy reveal about a Central Bank's Preferences? Economic Notes, v.32, n3, p. 335-359, 2003.

Model Uncertainty, optimal monetary policy and the preferences of the Fed. Scottish Journal of Political Economy, v 51,n 1, p. 105-125.2004.

Castillo, P.; Humala, A.; Tuesta, V. Política monetaria, cambios de régimen de política monetaria e incertidumbre inflacionaria en el Perú (1949-2006). Documento de Trabajo, Banco Central de Reserva del Peru, n. 5, 2007a. Disponível em:< http://www.bcrp.gob.pe/docs/Publicaciones/ Documentos-de-Trabajo/2007/Working-Paper-05-2007.pdf > . Acesso em: 17 de Abr. 2009. 
Castillo, P.; Montoro, C.; Tuesta, V. Hechos estilizados de la economía peruana. Revista de Estudios Económicos del Banco Central de Reserva Del Peru, n. 14, $2007 \mathrm{~b}$.

Cecchetti, S.G.; Krause, S. Financial Structure, Macroeconomic Stability and Monetary Policy. National Bureau of Economic Research, n. 8354, 2001.

Cecchetti, S.G.; Ehrmann, M. Does inflation targeting increase output volatility? An international comparison of policymakers' preferences and outcomes. Cambridge: National Bureau of Economic Research, n.7426, 1999.

Cecchetti, S.G.; McConnell, M; Quiroz, G. Policymakers' Revealed Preferences and the Output-Inflation Variability Trade-Off: Implications for the European System of Central Banks. The Manchester School, v.70, n. 4, p. 596-618, 2002.

Chong, Y.; Hendry, D. Econometric Evaluation of Linear Macro-economic Models. Review of Economic Studies, v. 53, n. 4, p. 671-690, 1986.

Collins, S.; Siklos, P. L. Optimal monetary policy rules and inflation targets: are Australia, Canada, and New Zealand different from the U.S.? Open Economies Review, v.15, n.4, p. 347- 362, 2004.

Chow, G. Estimation of Rational Expectations Models. American economic Review, v. 71, n. 2, p. 211-216, 1981.

Dennis, R. The policy preferences of the US Federal Reserve. Journal of Applied Econometrics, v.21, n.1, p. 55- 77, 2006.

. Inferring Policy Objectives from Economic Outcomes. Journal of Oxford Bulletin of Economics and Statistics, v.66, n. 1, p. 735-764, 2004.

Departamento de Modelos Macroeconômicos BCRP. Modelo de Proyección Trimestral del BCRP. Documento de Trabajo, Banco Central de Reserva del Peru, n. 6, 2009. Disponivel em: < http:// www.bcrp.gob.pe/docs/Publicaciones/Documentos-de-trabajo/2009/Documento-Trabajo-06-2009. pdf. >. Acesso em: 17 de Abr. 2009.

Estrella, A.; Fuhrer, J. Dynamic Inconsistencies: Counterfactual Implications of a Class of Rational Expectations Model. American Economic Review, v.96, n. 4, p.1013-1028,2002.

Miranda, M.; Fackler, P. Applied Computational Economics and Finance. Massachusetts: The MIT Press, p. 288- 292, 2002.

Favero, C. A.; E Rovelli, R. Macroeconomic Stability and the preferences of the Fed: A formal analysis,1961-98. Journal of Money, Credit, and Banking, v. 35, n. 4, p 545-556, 2003.

Fuhrer, J. The (un) importance of forward-looking behavior in price specifications. Journal of Money, Credit and Banking, v. 28, n. 3, p. 338-350.1997.

Goñi, P. A.; Ormeño, S.A. Modelación e Identificación de las Preferencias Del Banco Central en la Aplicación de Política Monetária,1999.Consorcio de Investigación Económica e Social ( CIES) e Universidad Del Pacifico Centro de Investigación, (CIUP). Documento de Trabalho, disponível em: < http://www.cies.org.pe/docs/investigaciones/politica-macroeconomica-y- crecimiento/ preferencias-banco-central> . Acesso 04 de Abr. 2009

Hansen, L.; Sargent, T. Formulating and estimating dynamic linear rational expectations models. Journal of Economic Dynamics and Control, v.2, 1980.

.Recursive models of dynamic linear economies. 2004. Mimeo.

Ilbas, P. Revealing the preferences of the US Federal Reserve. Bank of Norges, Working Paper, n. 21, 2008.

King, M. Changes in UK Monetary Policy: Rules, Discretion in Practice. Journal of Monetary Economics, v. 39, n. 1, p. 81-97, 1997.

Leiderman, L.; Maino, R.; Parrado, E. Inflation targeting in Dollarized Economies. IMF Working paper, n. 157,2006

Ljungqvist, L.; Sargent, T. Recursive macroeconomic theory. $2^{\text {a }}$ ed. Cambridge: MIT Press, Chapter n.5, 2004. 
Lucas, R. Econometric policy evaluation a critique. Carnegie-Rochester Conference Series on Public Policy, v.1, p. 19-46, 1976.

MINISTERIO DE ENERGIA Y MINAS PERU. Anuário Minero 2007. Disponível em: < http://www. minem.gob.pe/publicacion.php?idSector=1\&idpublicacion=20>. Acesso em 12 de Nov. 2009

Ozlale, U. price stability vs. Output stability: tales of Federal reserve administrations. Journal of Economic Dynamics and Control, v. 17, n. 9, p.1595-1610, 2003.

Quezada, W. D. Reglas Monetarias para América Latina un Enfoque Computable. Banco Central de Reserva Del Peru, 2004. Disponível em: < http://www.cemla.org/pdf/red/PE_diego_winkenried. pd f $>$. Acesso em: 18 de Nov. 2009.

Rodriguez, G. Eficiencia de la Política Monetaria y la Estabilidad de las preferencias del Banco Central una evidencia para el Perú. Revista de Estudios Económicos del Banco Central de Reserva Del Peru, n. 15, 2008.

.Stability of Central bank Preferences, Macroeconomic Shocks, and Efficiency of the Monetary Policy, Empirical Evidence for Canada. University of Ottawa, Working Paper, n. 603, 2006.

Rojas, C. F. El efecto del suavizamiento de la tasa de interes em uma regla de política monetária bajo um régimen de "Inflation Targeting": el caso peruano. Documento de Trabajo, del Banco Central de Reserva Del Peru, n.15,2001. Disponível em: < http://www.bcrp.gob.pe/docs/Publicaciones/ Documentos-de-trabajo/2001/Documento-Trabajo-01-2001.pdf >. Acesso em: 18 de Abr. 2009.

Rudebusch, G. D.; Svensson, L. E. O. Policy rules for inflation targeting. In: Taylor, JB (ed). Monetary policy rules. Chicago: The University of Chicago Press, 1999.

Sack, B.; Wieland, V. interest-rate smoothing and optimal monetary policy: a review of recent empirical evidence. Journal of Economics and Business,v. 52, n.1-2, p. 205-228, 2000.

Salemi, M. K . Revealed Preference of the Federal Reserve: Using Inverse-Control Theory to Interpret the Policy Equation of a Vector Autoregression. Journal of Business \& Economic Statistics, v. 13, n. 4, p. 419-433,1995.

Salas, J. ¿Qué explica las fluctuaciones de la inflación en el Perú en el periodo 2002 - 2008? Evidencia de un análisis VAR estructural, Revista de Estudios Económicos del Banco Central de Reserva Del Peru, n. 16, 2009.

Söderlind, P.; Söderström, U.; Vredin, A. Can calibrated New-keynesian models of monetary policy fit the facts? Stockholm: Sveriges Riksbank, 2002, Working paper, n. 140.

Svensson, L. E. O. Inflation Targeting as a Monetary Policy Rule. Journal of Monetary Economics, v. 43, p. 607-654, 1999.

Tachibana, M. Central Bank's preferences in Japan, the UK, and the US. Japan and the World Economy, v.16, p. 81-93, 2004.

Taylor, J. B. Discretion versus policy rules in practice. Carnegie- Rochester conference series on Public Policy, v. 39, 1993.

. A Historical analysis of Monetary Policy Rules. National Bureau of Economic Research, Working Paper, n. 6768, 1998.

Woodford, M. Optimal Interest Rate Smoothing. Review of Economic Studies, v. 70, p. 861-886. 2004

.Pitfalls of Forward Looking Monetary Policy. American Economic Review Papers and Proceedings, v. 90, p 100-104. 2000.

Walsh, E. C. Monetary Theory and Policy. $2^{\mathrm{a}}$ ed. Cambridge, Massachusetts: The MIT Press, p. 323325, 2003. 